\title{
Determinants of Wheat Market Outlet Choice of Cooperative Members: The Case of Hetosa District, Ethiopia
}

\author{
${ }^{1}$ Abebe Negeri, ${ }_{2}^{2}$ Professor Ji Quan \\ ${ }^{1,2}$ School of Management, Wuhan University of Technology, Wuhan, P.R.China, 430070
}

\begin{tabular}{|c|c|}
\hline & ABSTRACT \\
\hline $\begin{array}{l}2016 \text { Research Leap/Inovatus Services Ltd. } \\
\text { All rights reserved. } \\
\text { DOI: } 10.18775 / \text { jibrm.1849-8558.2015.61.3001 } \\
\text { URL: } \text { http://dx.doi.org/10.18775/jibrm.1849- } \\
\underline{\text { 8558.2015.61.3001 }}\end{array}$ & \multirow{2}{*}{$\begin{array}{l}\text { It is assumed that, agricultural cooperatives are solving members marketing problem. However, } \\
\text { members were not properly used cooperatives as market outlet in the study area. The specific } \\
\text { objectives of the study were to assess wheat market outlet choices and analyze factors that } \\
\text { determine wheat market outlet choices of members. The survey research method was used to } \\
\text { accomplish this. The primary data were collected from } 134 \text { randomly selected respondents. The } \\
\text { secondary data specific to the study area were collected from documents and records of } \\
\text { agricultural cooperatives. The data was analyzed using the descriptive statistics and binary } \\
\text { logistic regression. The analysis showed that only } 23.10 \% \text { of sample respondents were selling } \\
\text { their wheat produce through cooperatives where as } 76.90 \% \text { were selling to other market outlet } \\
\text { than cooperatives. The model showed that eight variables have a significant effect on the wheat } \\
\text { market outlet choices of members. Those are education, dividend payment, quantity produced, } \\
\text { access to training, access to extension service, market information, and trust on cooperatives, } \\
\text { have a positive significant effect on wheat market outlet choices of members while mode of } \\
\text { sell/payment system have a negative significant effect. Based on the study results, the following } \\
\text { recommendation were given to choose cooperatives as a market outlet. Necessary training } \\
\text { concerning the benefits of cooperatives in general and marketing in particular should be given } \\
\text { to cooperatives by concerned body. There should be trust among members and cooperative } \\
\text { leaders. Dividend must be paid based on the cooperative bylaws. Appropriate extension service } \\
\text { must be given to cooperative members so as to increase the quantity of produces. In addition, } \\
\text { providing marketing information timely is very crucial. Finally, mode of sell/payment system } \\
\text { is advisable if it is on cash instead of paying on credit. }\end{array}$} \\
\hline $\begin{array}{l}\text { Keywords: } \\
\text { Cooperative, Determinants, Market outlet choice, } \\
\text { Members, Wheat market outlet }\end{array}$ & \\
\hline
\end{tabular}

\section{Introduction}

Agriculture is the most important sector of Ethiopia's economy. Wheat is the first important and strategic cereal crop for the majority of world's populations including Ethiopia. It plays a great role for the development of agricultural sector and improvement in the income levels and livelihood situations of the farmers in developing countries. According to FAOSTAT cited by Abebe et al. 2018, the second top wheat producer country in Africa, next to Egypt is Ethiopia on 2015/2016 production season. This implies that there is a huge potential of wheat yield in the country. It is the fourth important crop in term of total gross value production and the second importance food next to maize in Ethiopia (CSA, 2015). According to Tesfaye et al. 2018 citing Kelemu 2017, wheat is one of the known crops in the country in terms of both production and consumption. Also it is important crop to consume in deferent forms in Ethiopia and the rest of the world. Wheat is grown in the highlands of the country at altitudes of 1500 to 3000 meter above sea level.
Hetosa District is the known district in production of wheat in Ethiopia (CSA, 2011). Out of the total production of wheat produced, consumption and marketing take the largest share because, it is the most important and widely known cash crop of the area. As it is one of the cash crops of the areas, organizing agricultural cooperative societies has become mandatory to solve market related problems. In principle, cooperative members are supposed to sell their produce to primary cooperatives. However, from own experience, observations, and from preliminary study done before, cooperative members are selling their produce more to non-cooperative firms than selling to cooperatives. This has reduced members' marketing participation, which in turn has impact on the development of cooperatives. In studies made earlier, the exact market outlets chosen by members of cooperatives are not significantly known. Besides, the reasons why members sell their produce to other markets than cooperatives have not been studied in the area as to the knowledge of the researcher. This study is, therefore, designed to bridge the above-mentioned gap with the aim of 
assessing members' market outlet choices; and analyzing determinants of members' wheat market outlet choices in the study area

\section{Literature Review}

\subsection{Cooperative Marketing}

Most developing countries, including Ethiopia, are returning to agricultural cooperatives to address market failures and to cope with shifts in the business climate (Nicola 2009). This is because cooperatives can reduce transaction costs and improve the negotiating power of visa-a-vis increasingly integrated markets for smallholder farmers. In line with this, the government of Ethiopia advocates agricultural cooperatives especially marketing cooperatives as the main pillars of development and key market institutions in its Led Industrialization Strategy for Agricultural Growth. This plan aims to unlock Ethiopia's agricultural growth potential by providing a better institutional environment for integrating smallholder farmers into international market (Amdissa 2006).

\subsection{The Concept of Market Outlet Choices}

Market outlet is the final market place to deliver dairy products into which it may pass from different channels (Kuma 2013). Similarly, wheat market outlet is the final market place to deliver the products.

\subsection{Factors Affecting Market Outlet Choices}

There are a number of empirical studies exist regarding factors affecting farmers channel choice decision. Addisu 2019 used Tobit model to identify factors that affect commercialization of teff producers' of smallholder farmers' in Dendi District of Oromia, Central Ethiopia. The result of Tobit regression model revealed that variables like education level of household head, nearest market distance, size of land under teff production, cooperative membership, livestock owned, agricultural extension, current market prices and non-farm income significantly affect commercialization level of teff producers.

Shewaye et al. 2016 identified factors that affects farmers' outlet choices of haricot bean in Southern Ethiopia Misrak Badawacho District by using multivariate probit model. The result of multivariate probit model showed that distance to market affect positively the probability to choose market outlet whereas number of equine owned and use of credit has a negative effect. Consumer outlet is positively affected by the number of equine owned. Distance to market negatively affect the probability to choose the urban traders outlet. Whereas market information, membership in cooperative, use of credit and number of equine owned are positively affect the probability to choose urban traders.

Takele.et al.2017 used multivariate probit model to determine the major determinants of the market outlet option of smallholder mango producers in Boloso Bombe Woreda, Wolaita region, Southern Ethiopia. The result showed that variables such as the size of family, distance from market and quantity of mango produced, amount of price given, market access and access to non-farm income dictated the choice of wholesalers, collectors and retailers and consumer outlets at different levels of significance.

Mekonin 2017 determine market channel choice and livelihood outputs of coffee producer farmers in Ethiopia Oromia Region at Lalo Assabi District and he reported that access to training, extension service, membership to cooperative, business volume, and non-farm income positively affects cooperative market outlet. Based up on the above literature the following conceptual framework model was developed.

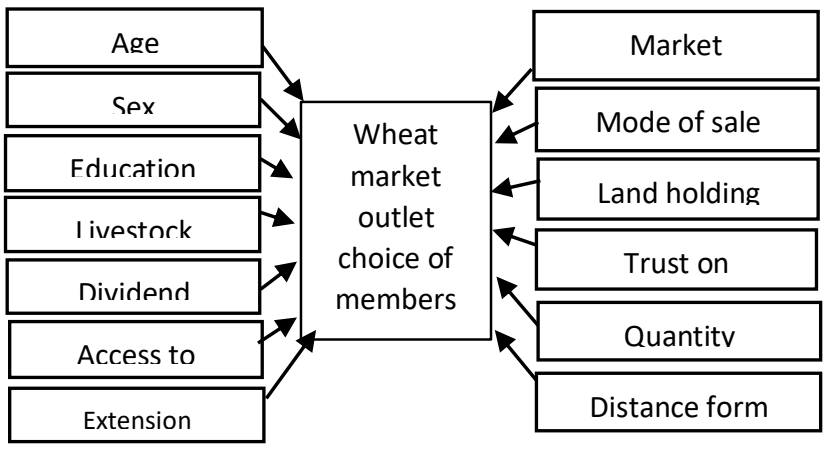

Figure 1: Conceptual Framework Model Source: Own Sketch

\section{Methodology}

In order to conduct the study from the total twenty-five (25) multi- purpose cooperative societies, five (5) primary agricultural cooperative societies were selected by purposive sampling technique based on the following criteria. Those are year of establishment, coverage of wider operational areas, potential of wheat production, and availability of required data.

\subsection{Sample Size Determination}

Again, from five (5) primary cooperative societies the respondents were selected in a representative way to increase its reliability and validity of the samples. Accordingly, the sample size of respondent was determined by using Kothari 2004 sampling design formula.

$$
\begin{aligned}
\mathrm{n}= & \underline{\mathrm{p} \cdot \mathrm{q} \cdot \mathrm{N} \cdot \mathrm{Z}^{2}} \\
= & \frac{(5,250)(0.1)(0.9)(1.96) 2}{(5,250-1)(0.05) 2+(0.1)(0.9)(1.96) 2} \\
= & \frac{1815}{13.50}=134 \text { Respondents }
\end{aligned}
$$

\subsection{Data Types and Data Sources}

Both qualitative and quantitative data were used in the study. The data were collected from both primary and secondary sources. Primary data were collected from 134 randomly selected respondents. The secondary data specific to the study area were collected from documents and records of agricultural cooperatives. 


\subsection{Data Collection and Analysis Method}

The data were collected by using survey questionnaire, keyinformant interview and FGD. To meet the first, and second specific objectives, both descriptive, and binary logistic regression model were used.

\section{Result and Discussion}

\subsection{Characteristics of the Sampled Respondents}

Table 1: Demographic factor

\begin{tabular}{|l|l|r|r|r|r|}
\hline Demographic variables & Valid & Frequency & Percent & $\begin{array}{l}\text { Valid } \\
\text { Percent }\end{array}$ & $\begin{array}{l}\text { Cumulative } \\
\text { Percent }\end{array}$ \\
\hline \multirow{4}{*}{ Age } & $20-40$ & 67 & 50.0 & 50.0 & 50.0 \\
\cline { 2 - 6 } & $41-60$ & 61 & 45.5 & 45.5 & 95.5 \\
\cline { 2 - 6 } & 61 and above & 6 & 4.5 & 4.5 & 100.0 \\
\cline { 2 - 7 } & Total & $\mathbf{1 3 4}$ & $\mathbf{1 0 0 . 0}$ & $\mathbf{1 0 0 . 0}$ & \\
\hline \multirow{3}{*}{ Sex } & Female & 115 & 11.2 & 11.2 & 11.2 \\
\cline { 2 - 7 } & Male & $\mathbf{1 3 4}$ & $\mathbf{1 0 0 . 0}$ & 88.8 & 100.0 \\
\cline { 2 - 7 } & Total & 72 & 53.7 & $\mathbf{1 0 0 . 0}$ & 53.7 \\
\hline Education & Illiterate/ Non-formal & 62 & 46.3 & 46.3 & 53.7 \\
\cline { 2 - 7 } & Formal education & $\mathbf{1 3 4}$ & $\mathbf{1 0 0 . 0}$ & $\mathbf{1 0 0 . 0}$ & 100.0 \\
\cline { 2 - 6 } & Total & & & & \\
& & & & &
\end{tabular}

Source: Computed from field survey data (2020)

From the total 134 member respondents $88.8 \%$ were male, and the remaining $11.2 \%$ were females. This shows that, majority of members of agricultural cooperatives were male headed. It was found that from the total respondents about $50 \%, 45.5 \%$, and $4.5 \%$ were in the age range of 20-40, 41-60, and above 60 , respectively. In this case, the mean of age is 42 years. Regarding level of education; from the data collected, it was found that among the total respondents $53.7 \%$ and $46.3 \%$ of them was illiterate/ non-formal education and had formal education respectively. The mean of land holding, livestock holding, quantity produced, and distance from market were 3 hectares, 8TLU, 20 quintals, and 8 kilometers respectively.

\subsection{Distribution of Respondents by Wheat Market Outlet Choices}

Table .2: Distribution of respondents by wheat market outlet choices

\begin{tabular}{|l|c|c|}
\hline Market outlet & $\begin{array}{c}\text { Frequenc } \\
\text { y }\end{array}$ & Percent \\
\hline Cooperatives & 31 & 23.1 \\
\hline $\begin{array}{l}\text { Other than } \\
\text { cooperatives }\end{array}$ & 103 & 76.9 \\
\hline Total & 134 & 100 \\
\hline
\end{tabular}

Source: Computed from field survey data (2020)

The wheat market outlet choices of members in the study area were cooperative and other than cooperative market outlet like consumers, petty traders, retailers, and whole sellers. From the total respondents $23.10 \%$ of them have chosen cooperative, while $76.90 \%$ of them have chosen other market outlet than cooperatives. This showed that majority of the members preferred other market outlet than cooperatives. According to the result of focus group discussion and key informant interviews the major reasons were: absence of training, lack of trust on cooperative and leaders or lack of sense of ownership of members and leaders, lack of education, absence of dividend payment, less quantity produced, lack of market information, poor payment system /mode of sell/, lack of cooperative extension services, absence of sufficient capital, and relatively less price provision.

\subsection{Statistical Result for Binary Logistic Model}

To know the determinant factors that affect wheat market outlet choices of members' binary logistic regression model were used. Before running the variables in the model the existence of multicollinearity problem were checked. Then from thirteen (13) variables were put in the model eight (8) variables were significantly affecting wheat market outlet choices of members. Those variables are education, dividend, quantity produced, training, market information, extension service, mode of sale or payment system, and trust on cooperative

Table 3: Parameter Estimates for Binary Logit (Variables in the Equation)

\begin{tabular}{|l|c|c|c|c|c|c|}
\hline Explanatory Variables & Coefficient (B) & S.E. & Wald & Df & Sig. & $\operatorname{Exp(B)~}$ \\
\hline AGE & 1.140 & 1.240 & .747 & 1 & .243 & 2.380 \\
\hline SEX & .083 & 1.203 & .004 & 1 & .832 & 1.088 \\
\hline EDUC & 1.164 & .643 & 1.761 & 1 & $.031^{* *}$ & 2.470 \\
\hline LIVESTOCK & 1.750 & 1.308 & .000 & 1 & .888 & 5.322 \\
\hline LAND & .218 & .682 & .161 & 1 & .567 & 1.280 \\
\hline DIVI & 1.177 & 1.064 & 3.131 & 1 & $.000^{* * *}$ & 7.811 \\
\hline QUANTPRO & 1.410 & .835 & 1.437 & 1 & $020^{* *}$ & 3.418 \\
\hline TRIAINING & 1.714 & 1.526 & 2.264 & 1 & $.000^{* * *}$ & 15.733 \\
\hline MARINFO & 1.187 & 1.226 & .147 & 1 & $.041^{* *}$ & 2.166 \\
\hline EXTENSION & .120 & .116 & 2.141 & 1 & $.061^{*}$ & 1.147 \\
\hline MODEOFS & -1.377 & 1.407 & 1.574 & 1 & $.041^{* *}$ & .072 \\
\hline TRUST & 1.566 & 1.247 & 2.774 & 1 & $.000^{* * *}$ & 13.430 \\
\hline DISTFROMA & .245 & .127 & 1.138 & 1 & .123 & 1.317 \\
\hline Constant & 1.272 & 1.560 & 0.157 & 1 & 0.000 & 6.456 \\
\hline
\end{tabular}

A Variable(s) entered on step 1: AGE, SEX, EDUC, LIVESTOCK, LAND, DIVI, QUANTPRO, TRAINING, MARINFO, EXTENSION, MODEOFS, TRUST, and DISTFROMA.

*** Significant at $1 \%$ probability level

** Significant at 5\% probability level

* Significant at $10 \%$ probability level

Exp (B) is the predict change in odds for a unit increase in the predictor.

Source: Computed from field survey (2020)

As displayed on table 4.3 out of the thirteen explanatory variables eight of the variables were found to be significantly influencing members' wheat market outlet choices in the study area. In terms of significances, three variables found to have significant influence on the market outlet choices of members with less than $1 \%$ probability level. These variables were 
dividend (DIVI), access to training (TRANING), and trust (TRUST). Four variables were significant at less than 5\% probability level. These variables were education (EDUC), market information (MARINFO), mode of sale (MODEOFS), and quantity produced (QUANTPRO). In addition, the rest one variable was significant to affect the market outlet choices of members at less than $10 \%$ probability level. This variable was extension (EXTENSION). The other five explanatory variables such as age (AGE), sex (SEX), livestock (LIVESTK), landholding (LAND), and distance from market (DISTFROMAR) though they have some partial effect on member's wheat market outlet choices, they were not statistically significant. As a result, their effect will not be dealt.

The effect of each of the statistically significant explanatory variables are interpreted and discussed here under using the result of the odds ratio, in the logistic regression model.

Education: - In the analysis model, education had a significant effect at $5 \%(\mathrm{P}<0.031)$ and positive association with the market outlet choice. The odd ratio for educational level indicates that with the assumption of other things being constant the probability of choosing cooperative market outlet increases by a factor of 2.470 as educational level increased by one unit.

Dividend: - In accordance with the expectation, payment of dividend for members affects members' cooperative market outlet choices positively and significant at $1 \%$ significance level $(\mathrm{P}<0.001)$. The implication is that by getting dividend members are initiated and selling wheat through cooperatives more and the vise versa. This means that other things kept constant, the odd ratio in favor of user members' increases by a factor of 7.811 as dividend payment increases by one unit.

Quantity produced: - This variable influenced the dependent variable positively at $5 \%$ significance level $(\mathrm{P}<0.020)$. As the quantity produced of the respondent increases by one unit, the probability of choosing cooperatives as market outlet increases by 3.418 times. This means members who produced more wheat chooses cooperative as market outlet than those of members who produced less. This is in line with the finding of (Takele.et al.2017).

Training: - It is positively correlated with the dependent variable and statistically significant at $1 \%$ significance level $(\mathrm{P}<0.001)$. The odd ratio for the access to training opportunity indicates that with the assumption of ceteris paribus, the probability of choosing cooperative market outlet increases by a factor of 15.733 as training opportunity increased by one unit.

Market information: - The variable affects the dependent variable positively at $5 \%$ significant level $(\mathrm{P}<0.041)$. As members access to market information the probability of choosing cooperative market outlet increases by a factor of
2.166. This finding is also the same as the finding of (Shewaye et.al 2016).

Extension: - The variable is positively affecting the dependent variable and statistically significant at $10 \%$ significant level (P $<0.061)$. This implies that a unit increase in the skill and knowledge of members through extension service will increase the likelihood that members will choose cooperatives as a market outlet by the value of the odds ratio 1.147.

Mode of sell: - This variable is affecting the dependent variable negatively and statistically significant at $5 \%$ significance level ( $\mathrm{P}<0.041)$. This means as members sell their wheat on credit to cooperatives the likelihood that they choose cooperatives as a market outlet will decreased by the value of the odds ratio 0.072 .

Trust: - It has positive relationship with the dependent variable and statistically significant at $1 \%$ significant level $(\mathrm{P}<0.001)$. The implication is an increase of members trust on their cooperatives will increase the likelihood that they will choose cooperatives as a market outlet by the value of the odds ratio 13.430 .

\section{Conclusion and Recommendation}

From the result of the study it is possible to conclude that, presence of dividend payment, access to training and trust on cooperatives have the expected sign and significant at $1 \%$ level of significance. Access to market information, extension service and payment system is determines significantly the probability of members in choosing cooperative market outlet. Moreover, when quantity produced and education level is increased, also there is an increase of the probability of members to choose cooperatives as market outlet.

\subsection{Recommendations}

The study result shows $(76.90 \%)$ of the respondents did not use cooperative as market outlet. This is because members have no adequate training on cooperative benefits in general and marketing in particular. Therefore, the cooperative promotion office of the District, Zone and Hetosa agricultural farmers' cooperative union must give attention in providing appropriate training especially on the marketing activities of the members. Second, there is lack of trust among members and cooperative leaders. Therefore, concerned body should give education and awareness on cooperative principles, values and ethical values for both members and leaders so as to develop trust through applying the cooperative principles, and values. Third, the leaders should pay dividend based on their bylaws to encourage the marketing participation of members. Fourth, extension service given is very low. So, concerned government body should allocate those cooperative professionals on cooperative extension services to adequately reach the cooperative members. Fifth, Cooperatives must work on income generating activities like supplying consumer goods to its members, and selling additional share so as to buy members produce in cash and give 
competitive price. Sixth, cooperative members have lack of market information. So, the marketing department of District cooperative promotion should give market information timely to cooperative. The other thing is from the result some private traders are cheating in balance and adulterating members produce. Therefore, concerned government body should take corrective action through education and awareness on those traders who are adulterating the farmers produce.

Finally, this study is limited to one district only, which makes difficult to generalize and make inference to the whole region or country. Thus, there is a need to make an in-depth study in this regard by considering other variables and districts of the region or the country so as to clearly identify the determinants of wheat market outlet choices of members, and to design appropriate strategy to enhance members' participation in marketing their produce through cooperatives.

\section{References}

- Abebe, Tadie, \& Taye. (2018). Factors affecting market outlet choice of wheat producers in North Gondar Zone, Ethiopia: Journal of Agriculture \& Food Security.

- Addisu Getahun. (2019). Determinants of Commercialization of Tef: The Case of Smallholder Farmers in Dendi District of Oromia, Central Ethiopia: International Journal of African and Asian Studies, 56 (2409-6938) pp 114.

- Amdissa Teshome. (2006). Agricultural, Growth and Poverty Reduction in Ethiopia: Report pp 15-16.

- Berhanu Kuma. (2013) .Factors Affecting Milk Market Outlet Choices in Wolaita Zone, Ethiopia: African Journal of Agricultural Marketing, 1 (2) 024-031.

- C.R. Kothari. (2004). Research Methodolgy Methods and Techniques Second Revised Edition Book. New Age International Publishers New Dehli India, pp 172-180.

- Central Statistics Aouthority (CSA) of Ethiopia. (2015). Report on Area and Production of Major Crops, pp. 11-13.

- Gain Nicola Francesconi. (2009) Cooperation for compettion: linking Ethiopian farmers to markets: Dissertation pp 19-20. Crossref

- Mokonin. (2017). Determinants of Market Outlet Choice of Coffee Producing Farmers in Lalo Assabi District, West Wollege Zone, Ethiopia: Journal of Economics and Development, 19 (2) pp. 48-67 Crossref

- Shawaye et. al. (2016). Determinants of Harcot Bean Market Participation in Misrak Badawacho District, Hadiya Zone, Southern Nations Nationalities and Peoples Regional Stae, Ethiopia: Ethiop. J. Agric. Sci., 26(2) 69-81.

- Takele, Endrias \& Amsalu. (2018). Determinants of Market Outlet Choice of the Smallholder Mango Producers: The Case of Boloso Bombe Woreda, Wolaita Zone, Southern Ethiopia: A Multivariate Probit Approach: Global Journal of Science Frontier Research USA, 17(2) 4-6.

- Tesfaye et al. (2018). Impact of Improved Wheat Variety on Productivity in Oromia Regional State, Ethiopia Greener Journal of Agricultural Sciences, 8(4), pp. 074-081. Crossref 